Conclusion: The SARS-CoV-2 prevalence in IMID patients over the study period seems to be similar to that of the general population ${ }^{1}$. The IMID inflammatory status seems to be independently associated with the development of COVID-19.

REFERENCES:

[1] Pollán $M$, Pérez-Gómez $B$, Pastor-Barriuso $R$, Oteo J, Hernán $M A$, Pérez-Olmeda M, et al. Prevalence of SARS-CoV-2 in Spain (ENE-COVID): a nationwide, population-based seroepidemiological study. Lancet Lond Engl. 2020 Aug 22;396(10250):535-44.

Disclosure of Interests: None declared.

DOI: 10.1136/annrheumdis-2021-eular.3368

\section{POS0056 ANXIETY AND CONCERNS RELATED TO THE WORK SITUATION DURING THE COVID-19 PANDEMIC IN $>5,000$ PATIENTS WITH INFLAMMATORY RHEUMATIC DISEASE FOLLOWED IN THE DANISH DANBIO REGISTRY, RESULTS FROM A NATIONWIDE QUESTIONNAIRE}

B. Glintborg ${ }^{1}$, D. V. Jensen ${ }^{2}$, S. Engel ${ }^{1}$, L. Terslev ${ }^{1}$, M. Pfeiffer Jensen ${ }^{1}$, O. Hendricks ${ }^{3}$, M. Østergaard ${ }^{1}$, S. H. Rasmussen ${ }^{1}$, T. Adelsten ${ }^{4}$, A. Colic ${ }^{4}$, K. Danebod ${ }^{1}$, M. Kildemand ${ }^{5}$, A. G. Loft ${ }^{6}$, H. L. Munk ${ }^{7}$, J. K. Pedersen ${ }^{8}$, R. Østgård ${ }^{9}$, C. M. Sørensen ${ }^{10}$, N. Steen Krogh ${ }^{11}$, J. Nørgaard Agerbo ${ }^{12}$, C. Ziegler ${ }^{12}$, M. L. Hetland ${ }^{1} .{ }^{1}$ Centre of Head and Orthopedics, Rigshospitalet, DANBIO and Copenhagen Center for Arthritis Research (COPECARE), Center for Rheumatology and Spine Diseases, Glostrup, Denmark; ${ }^{2}$ Gentofte and Herlev Hospital, Department of rheumatology, Center for Rheumatology and Spine Diseases, Gentofte, Denmark; ${ }^{3}$ University Hospital of Southern Denmark, Sønderborg, Danish Hospital for Rheumatic Diseases, Sønderborg, Denmark; ${ }^{4}$ Zealand University Hospital, Department of Rheumatology, Køge, Denmark; ${ }^{5}$ Odense University Hospital, Department of Rheumatology, Odense, Denmark; ${ }^{6}$ Aarhus University Hospital, Department of Rheumatology, Aarhus, Denmark; ${ }^{7}$ Odense University Hospital, Department of Rheumatology, Odense, Denmark; ${ }^{8}$ Odense University Hospital and Svendborg Hospital, Department of Rheumatology, Odense and Svendborg, Denmark; ${ }^{9}$ Silkeborg Regional Hospital, Diagnostic Center, Silkeborg, Denmark; ${ }^{10}$ Horsens Regional Hospital, Department of Medicine, Horsens, Denmark; ${ }^{11}$ ZiteLab Aps, Copenhagen, Denmark; ${ }^{12}$ Gigtforeningen/Danish Rheumatism Association, Copenhagen, Denmark

Background: During the COVID-19 pandemic, widespread changes in how we work have been observed. Working from home is not an option for everyone. At work it may be difficult to keep social distance, which may lead to fear and anxiety of being infected with SARS-CoV-19 or of spreading the virus.

Objectives: To explore frequency of anxiety and concerns related to work in patients with inflammatory rheumatic diseases(IRD) during the COVID-19 pandemic and to identify patient and disease characteristics associated with increased anxiety.

Methods: Patients in routine care followed in the nationwide Danish DANBIO registry were invited to answer an on-line questionnaire regarding current rheumatic disease activity, behavior and anxiety including current work-status and -concerns. Responses were linked to patient data previously recorded in DANBIO. Clinical factors associated with work-related concerns (completely/mostly agree versus neither/nor, completely/mostly disagree) were explored with multivariable logistic regression

Results: Among 14,758 respondents (38\% of eligible patients), 5,950 patients $(40 \%)$ were currently working $(60 \%$ full time/31\% part time/ $9 \%$ self-employed) $(61 \%$ female, $53 \%$ rheumatoid arthritis $/ 19 \%$ psoriatic arthritis/20\% axial spondyloarthritis/9\% other). Although $68 \%$ reported that the workplace helped to make necessary interventions, work-related concerns and anxiety were frequent. Thus, $22 \%$ found it difficult (completely/mostly agree) to keep physical distance at work and $20 \%$ were worried about going to work (Figure 1).

Factors associated with concerns about going to work were female gender, longer education, other chronic conditions, biological therapy, and higher (=poorer) EQ-5D, whereas diagnosis was without significance. Similar patterns were found for other work-related concerns (not shown).

Conclusion: In this cohort of $>5,000$ patients with inflammatory rheumatic diseases followed in a nationwide registry, during the COVID-19 pandemic anxiety and concerns related to the work situation were frequent, especially in women and patients treated with biologicals, with other chronic diseases and with poor quality of life.

\section{REFERENCES:}

[1] Glintborg et al, 2021, https://rmdopen.bmj.com/content/rmdopen/7/1/ e001505.full.pdf Figure. Concerns related to work situation in 5,950 patients with inflammatory arthritis during
the COVID-19 pandemic in November 2020

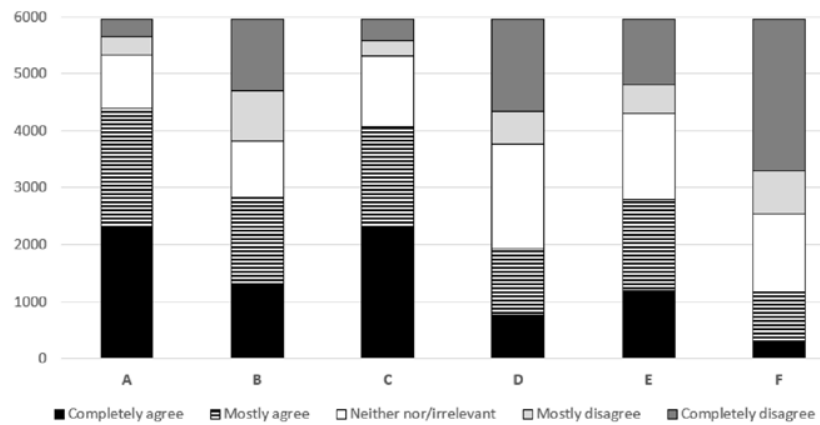

Questions: A: It is important for me to keep physical distance at my job, B: It is difficult for me to keep physical distance at my job, C: My work-place helped to make necessary interventions for me to safely tend my job, D: I fear that my arthritis condition increases my risk of COVID-19 infection at work more than others my age, E: Due to my arthritis condition I should take more precautions at work to avoid infection compared to others my age, F: I am worried to go to work

Table 1. Factors associated with being worried (agree versus disagree) to go to work (Figure 1, panel F). Multivariable logistic regression analyses

\begin{tabular}{llll}
\hline & & Odds ratio $(95 \% \mathrm{Cl})$ & $\mathrm{p}$ \\
\hline Gender & female & 1 & \\
& male & $0.45(0.38 ; 0.54)$ & $<0.001$ \\
Age, years & 40 & 1 & \\
& $40-60$ & $1.12(0.87 ; 1.44)$ & 0.4 \\
Education & $>60$ & $0.89(0.67 ; 1.20)$ & 0.5 \\
& Long & 1 & \\
Living alone, yes & No/short & $0.80(0.69 ; 0.93)$ & 0.005 \\
Other chronic condition, yes & & $0.97(0.79 ; 1.20)$ & 0.8 \\
Biological therapy & & $1.37(1.17 ; 1.59)$ & $<0.001$ \\
Diagnosis & Rheumatoid arthritis & $1.36(1.17 ; 1.58)$ & $<0.001$ \\
& Psoriatic arthritis & $1.21(0.99 ; 1.48)$ & 0.06 \\
& Axial spondyloarthritis & $1.03(0.84 ; 1.28)$ & 0.8 \\
PASS, yes* & Other & $1.17(0.89 ; 1.54)$ & 0.3 \\
Smoking & & $1.03(0.85 ; 1.25)$ & 0.7 \\
& Current & 1 & \\
EQ5D** & Previous & $1.17(0.94 ; 1.47)$ & 0.2 \\
& Never & $1.10(0.90 ; 1.35)$ & 0.4 \\
\hline
\end{tabular}

*patient acceptable symptom state, ${ }^{* \star}$ European Quality of Life, 5 dimensions

Disclosure of Interests: Bente Glintborg Grant/research support from: AbbVie BMS, Pfizer, Dorte Vendelbo Jensen: None declared, Sara Engel: None declared, Lene Terslev Speakers bureau: AbbVie, Janssen, Roche, Novartis, Pfizer, MSD, BMS and GE, Mogens Pfeiffer Jensen: None declared, Oliver Hendricks: None declared, Mikkel Østergaard Speakers bureau: Abbvie, BMS, Boehringer-Ingelheim, Celgene, Eli-Lilly, Hospira, Janssen, Merck, Novartis, Novo, Orion, Pfizer Regeneron, Roche, Sandoz, Sanofi and UCB., Grant/research support from: Abbvie, BMS, Celgene, Merck, Novartis, Simon Horskjær Rasmussen: None declared, Thomas Adelsten: None declared, Ada Colic: None declared, Kamilla Danebod: None declared, Malene Kildemand: None declared, Anne Gitte Loft Speakers bureau: AbbVie, Eli-Lilly, Janssen, MSD, Novartis, Pfizer, and UCB Heidi Lausten Munk: None declared, Jens Kristian Pedersen: None declared, René Østgård Speakers bureau: Abbvie, BMS, Boehringer-Ingelheim, Eli-Lilly, Janssen, Merck, Novartis, Pfizer, Roche, Sanofi and UCB., Grant/research support from: Abbvie, Christian Møller Sørensen: None declared, Niels Steen Krogh: None declared, Jette Nørgaard Agerbo: None declared, Connie Ziegler: None declared, Merete L. Hetland Grant/research support from: AbbVie, Biogen, BMS Celtrion, Eli Lilly Denmark A/S, Janssen Biologics B.V, Lundbeck Fonden, MSD, Pfizer, Roche, Samsung Biopis, Sandoz. MLH chairs the steering committee of the Danish Rheumatology Quality Registry (DANBIO), which receives public funding from the hospital owners and funding from pharmaceutical companies. $\mathrm{MLH}$ co-chairs the EuroSpA research collaboration, which generates real-world evidence of treatment of psoriatic arthritis and axial spondylorthritis based on secondary data and is partly funded by Novartis.

DOI: 10.1136/annrheumdis-2021-eular.721 